\title{
The Karoo-Ferrar Igneous Province: geochemical peculiarity, genesis and evolution
}

\author{
NADEZDA MIKHAYLOVNA SUSHCHEVSKAYA ${ }^{1}$, BORIS \\ V. BELYATSKY ${ }^{2}$ AND GERMAN LEITCHENKOV ${ }^{3}$ \\ ${ }^{1}$ Vernadsky Institude \\ ${ }^{2}$ VSEGEI,CIR \\ ${ }^{3}$ VNIIOkeangeolgia, St.Petersburg, Russia \\ Presenting Author: bbelyatsky@mail.ru
}

The Karoo-Ferrar Igneous Province: geochemical peculiarity, genesis and evolution

N.M.Sushchevskaya ${ }^{1 *}$, B.V.Belyatsky ${ }^{2}$, G.L. Leitchenkov ${ }^{3}$

${ }^{1}$ Vernadsky Institute of Geochemistry, RAS, Moscow, Russia (nadsus@gmail.com)

${ }^{2}$ Karpinsky Geological Institute (VSEGEI), St.Petersburg, Russia (bbelyatsky@mail.ru)

${ }^{3}$ VNIIOkeangeolgia, St.Petersburg, Russia

The spatial confinement of various geochemical types of flood basalts within southern Africa and East Antarctica is a unique feature of the plume-related magmatism that arose as a result of the specific evolution of the Mesozoic Karoo-plume. High-Ti basalts, and especially ferropicrites, widespread in the NuanetsiAhlmannryggen areas, apparently, can serve as a marker of the central, higher-temperature part of the plume, which penetrated into the lithosphere of Gondwana. Concentric zoning of the plume manifestation with a central, about $500 \mathrm{~km}$ radius, more uplifted part, is confirmed by geophysical data in the Antarctica [Leitchenkov, Masolov, 1997].

Significant negative $\mathrm{Nb}$ and $\mathrm{Ta}$ anomalies are characteristic of the melt sources of three regions (Karoo, Ferrar, and Queen Maud Land) associated with the Karoo plume. The same features are typical of the magma compositions of ancient dikes, which are widespread within the Ferrar province. It is assumed that the formation of the Ferrar igneous province occurred due to the lateral spread of magmatic material from the Karoo plume (in the form of a mega-apophysis from the main area) during the melting of the metasomatically altered Gondwana mantle under the influence of the Pacific subduction zone. The source of magmas in the Ferrar province could have been an ancient mantle, the melting of which led to the formation of magmatic provinces widespread in southern Africa and Antarctica. At the same time, under the influence of the mantle fluid, the primary melts of the Ferrar province were significantly enriched in such lithophile elements as $\mathrm{U}, \mathrm{Th}, \mathrm{Rb}$, and $\mathrm{Pb}$. In the coordinates of isotope ratios, the compositions of the studied basalts form an extended trend from the composition of a mantle source close to enriched low-Ti magmas of the Karoo province to the composition of a source with HIMU characteristics (increased values of ${ }^{206} \mathrm{~Pb} /{ }^{204} \mathrm{~Pb}: 20.5,{ }^{207} \mathrm{~Pb} /{ }^{204} \mathrm{~Pb}: 15.7,{ }^{208} \mathrm{~Pb} /{ }^{204} \mathrm{~Pb}: 40.3$, ${ }^{87} \mathrm{Sr} /{ }^{86} \mathrm{Sr}: 0.716$ and lower values $\left.{ }^{143} \mathrm{Nd} /{ }^{144} \mathrm{Nd}: 0.5124\right)$, which may reflect the composition of the subduction fluid. 